\title{
Research note: Mitigation of phosphorus, sediment and Escherichia coli losses in runoff from a dairy farm roadway
}

\author{
R.W. McDowell ${ }^{1,2}$, K. Daly ${ }^{3}$, O. Fenton ${ }^{3 \dagger}$ \\ ${ }^{1}$ AgResearch, Lincoln Science Centre, Private Bag 4749, Christchurch 8140, New Zealand \\ ${ }^{2}$ Faculty of Agriculture and Life Sciences, P O Box 84, Lincoln University, Lincoln 7647, Christchurch, New Zealand \\ ${ }^{3}$ Teagasc, Environment Research Centre, Co. Wexford, Ireland
}

Abstract

Dairy cow deposits on farm roadways are a potential source of contaminants entering streams. Phosphorus (P), suspended sediment (SS) and Escherichia coli (E. coli) loads in 18 runoff events over 12 mo from two-halves of a section of dairy farm roadway that spilt into an adjacent P-impacted stream were measured. The runoff from one half was untreated while the other half was directed through a filter of steel melter slag [termed aluminium chlorohydrate $(\mathrm{ACH})$-altered slag] sprayed with $1 \% \mathrm{ACH}$ solution to improve $P$ sorption capacity. An uncertainty analysis was conducted to ascertain potential loads of $P$ lost from roadways considering variation in deposit weight, number and $P$ content. Over the monitoring period, the total load decreased P (92\%), SS (98\%) and E. coli (76\%) from the ACHaltered slag roadway compared to the control. However, uncertainty analysis showed that the amount of dung-P deposited on the roadway could be 10 -fold greater.

Keywords

Contaminants $\cdot$ dung $\bullet$ laneway

\section{Introduction}

Roadways are used by vehicles and livestock within farm boundaries (termed lanes in New Zealand). On dairy farms, roadways are used by dairy cattle twice daily to go to the milking shed, during which time they deposit dung on the roadway. Runoff from these roadways is acknowledged as a significant source of contaminant transfer to nearby streams (Hively et al., 2006). However, apart from a few studies they remain an understudied part of farm scale losses. Monaghan \& Smith (2012) found that the concentration of faecal contaminants in runoff decreased with increasing distance away from the milking parlour. Furthermore, McDowell et al. (2007) found that in one case, runoff from a roadway accounted for $80 \%$ of the phosphorus $(\mathrm{P})$ load in a nearby stream. However, the amount of dung-P available for loss is highly variable depending on deposit weight, $\mathrm{P}$ content and number (Vadas et al., 2015).

Our objective was to determine the concentration of contaminants in roadway runoff and determine if the load and concentration of contaminants ( $\mathrm{P}$, Escherichia coli $[$ E. coli] and suspended sediment [SS]) could be decreased with a filter material as has been used to reduce $\mathrm{P}$ and SS loads in runoff from grassland and cropland (Ballantine \& Tanner, 2010; Buda et al., 2012; Karczmarczyk et al., 2016). We modified the filter material (steel melter slag) to increase $P$ sorption given the sensitivity of downstream waterbodies in the study area. To place the $\mathrm{P}$ results of the present study into a broader context an uncertainty analysis was conducted using ranges of values gathered from the literature pertaining to deposit weight, $\mathrm{P}$ content and number of deposits per hectare of roadway.

\section{Materials and methods}

\section{Site description and field setup}

The Mangakino stream feeds into the P-limited Lake Rerewhakaaitu (Abell et al., 2010, 2011), one of the Rotorua lakes. Land use within the catchment is representative of the surrounding area with a dominance of pastoral agriculture (70\% dairy, $7 \%$ sheep and beef, $15 \%$ forestry blocks and $8 \%$ other mixed land uses). In July $2006,200 \mathrm{~L}$ of a $1 \%$ solution of aluminium chlorohydrate $(\mathrm{ACH}$; Orica Chemicals, Newmarket, Auckland, NZ) was sprayed onto $2 \mathrm{t}$ of steel 
melter slag; hereafter called $\mathrm{ACH}$-altered slag. We chose to use $\mathrm{ACH}$-altered slag because of its high $\mathrm{P}$ sorption affinity and low cost and toxicity compared to other readily available products (McDowell et al., 2008). The $\mathrm{ACH}$-altered slag was placed in a 50-m long ditch that had been dug alongside one half of the roadway. On the other side, a similar ditch was dug but no $\mathrm{ACH}$-altered slag installed (Figure 1). The roadway cut across the stream, resulting in runoff discharging into the stream. At these points, a perforated polyvinyl chloride (PVC) pipe was connected to tipping-buckets to collect $\mathrm{ACH}$-altered slag and control runoff (Figure 1). The tipping buckets were calibrated to catch $1 \%$ of sample after each tip. Samples from the tipping buckets were collected in response to rainfall events $(>10 \mathrm{~mm}$ ) for $12 \mathrm{mo}$. A subsample of each water sample was filtered $(<0.45 \mu \mathrm{m}$ cellulose acetate syringe filter) and measured for dissolved reactive $P$ (DRP) and, after persulfate digestion, total dissolved $P$ (TDP). An unfiltered subsample was also measured for total $P$ (TP) after persulfate digestion (Eisenreich et al., 1975).

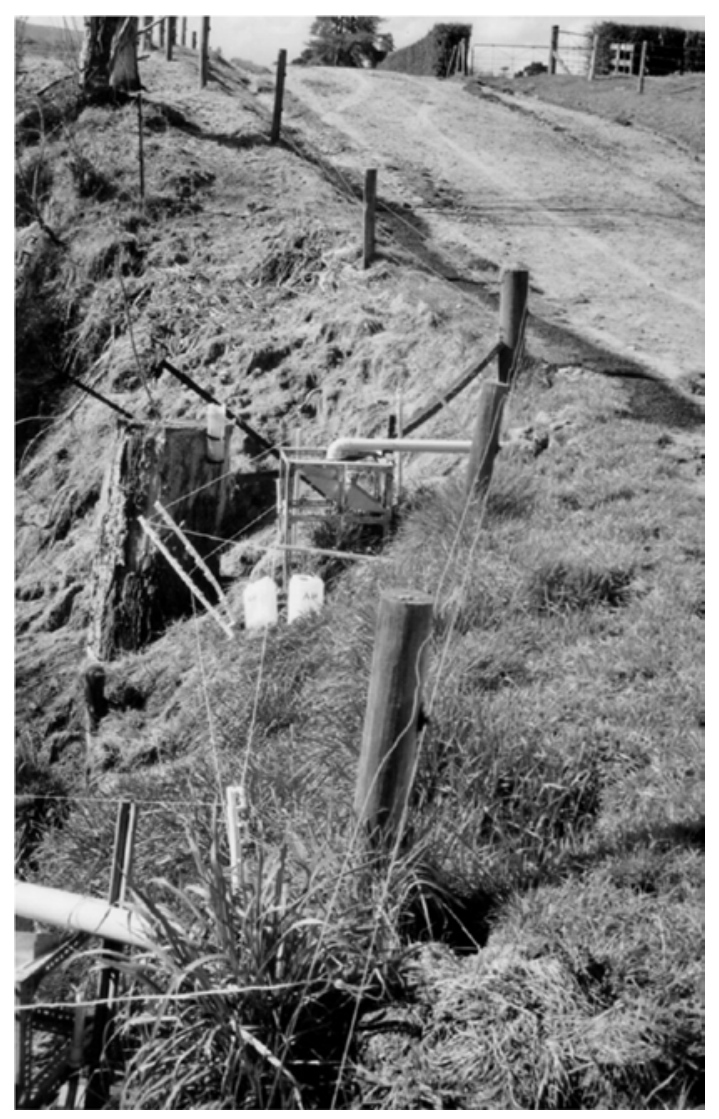

Figure 1. Picture showing one half of the road with $\mathrm{ACH}$-altered slag and tipping bucket installed. Note the Mangakino stream tributary flows through a culvert located beneath and between the two tipping buckets.
All $\mathrm{P}$ determinations were made colorimetrically (Watanabe \& Olsen, 1965). Dissolved organic P (DORP) was obtained by the difference of TDP-DRP, and particulate $P$ by the difference of TP-TDP. SS was determined on the remaining sample volume by filtration through a GF/A glass fibre filter paper and weighing the oven-dried $\left(105^{\circ} \mathrm{C}\right)$ residue. The faecal indicator bacteria - E. coli was enumerated using the Colilert $^{\circledR}$ media and the Quanti-Tray ${ }^{\circledR}$ system (IDEXX Laboratories, Westbrook, ME, USA). Data from runoff events during the year were checked for normality and logtransformed if necessary, before being analysed via a twotailed $t$-test of paired data. Data for concentrations were multiplied by the volume of runoff to calculate loads on a per event basis. These were summed across all events and expressed on a per hectare basis (viz. yield) assuming a catchment area of $200 \mathrm{~m}^{2}$.

\section{Uncertainty analysis}

An uncertainty analysis was conducted specifically for $P$ using an Excel-based Monte Carlo model. Inputs into the model were data ranges as in Table 1 for dung wet weight $(\mathrm{kg})$, number of deposits on roadway per ha, dung total $P$ concentration ( $\mathrm{g} / \mathrm{kg}$ dry weight). For the Monte Carlo analysis of total $\mathrm{P}$ deposited on a 1 ha section of roadway, we assumed all input variables had a uniform distribution. The model was run 1,000 times, whereby the model selected a value for each parameter within the range specified in Table 1. This enabled a probability distribution of outcomes to be achieved. The results of the present study were then compared to this full range of possible outcomes and loads were compared using the actual runoff data.

Table 1: Weight, frequency and $\mathrm{P}$ concentration of dairy cattle dung used in the uncertainty analysis

\begin{tabular}{lll}
\hline Parameter & \multicolumn{1}{c}{ References } \\
\hline Dung wet weight $(\mathrm{kg})$ & • & $1.5-2.6 \mathrm{~kg}$ (Haynes \& Williams, 1993) \\
range $=1.5-2.7$ & - & $2.0 \mathrm{~kg}$ (Krol et al., 2016; Bacher et al., 2018) \\
& $2.5 \mathrm{~kg}$ (Bell et al., 2015) \\
No of deposits on & Dairy cattle defecate 10.5 times/cow per day \\
roadway/ha cow $=$ & (Oudshoorn et al., 2008). Therefore, a low \\
$1-1.5$ & percentage of this could be on roadways \\
& Davies-Colley et al. (2004) investigated a \\
& 200 m roadway, 245 cows and showed that \\
& five deposits were made during each milking \\
& event \\
& Estimated for lactating dairy cattle \\
Dung P concentration & (McDowell, 2006; Vadas et al., 2015) \\
(g/kg dry weight) $=$ &
\end{tabular}




\section{Results}

\section{Field trial}

Data for the concentration of $\mathrm{P}$ fractions, SS and $E$. coli in runoff from the $\mathrm{ACH}$-altered slag and control section of the roadway are given in Table 2 , along with the probability of a significant difference $(P<0.05)$. In all cases, concentrations were greater in the control than in the $\mathrm{ACH}$-altered slag sections for DRP, PP, TP and SS. Concentrations of DRP, TP and SS were well in excess of recommended limits for freshwater eutrophication in disturbed (i.e. agricultural) lowland streams and for aquatic ecosystems and E. coli concentrations deemed fit for contact recreation (Australian and New Zealand Governments, 2018). However, this should only be taken as an indication of the potential to enrich the receiving stream and runoff will likely be diluted during stormflow. Contextually, concentrations of at least TP were like those noted for septic tank discharge (1-14 mg/L) (Withers et al., 2011).

The loads across all events along with the percent decrease due to treatment with $\mathrm{ACH}$-altered slag are given in Table 3. Loads from the $\mathrm{ACH}$-altered slag treatment were generally lower than from the control treatment except for DOP (-7\%), a $\mathrm{P}$ species that commonly exhibits poor sorption characteristics (Andersen et al., 2016). In contrast, $88 \%$ of DRP and $96 \%$ of PP species were mitigated by the $\mathrm{ACH}$-altered slag inferring that efficient sorption and filtration occurred. The efficiency of removal decreased with increasing event size, becoming ineffective for events with about $1,000 \mathrm{~L}$ of runoff, which equated to about $40 \mathrm{~mm}$ of rainfall (Figure 2).

\section{Uncertainty analysis}

Using the parameter ranges in Table 1, a probability distribution based on 1,000 runs of the model is shown in Figure 3 . This
Table 3: Loads of runoff, $P$ fractions, sediment and $E$. coli in the $\mathrm{ACH}$-altered slag and control roadways and the percentage mitigation (i.e. the fraction of load from $\mathrm{ACH}$-altered slag vs. control roadways)

\begin{tabular}{lccc}
\hline Parameter & $\begin{array}{c}\text { Mean load for } \\
\text { ACH-altered slag }\end{array}$ & $\begin{array}{c}\text { Mean load } \\
\text { for control }\end{array}$ & $\begin{array}{c}\text { Percent } \\
\text { decrease }\end{array}$ \\
\hline Runoff (L/ha) & $3,133,000$ & $3,243,750$ & 3 \\
DRP (kg/ha) & 0.3 & 2.5 & 88 \\
DOP (kg/ha) & 0.5 & 0.5 & -7 \\
PP (kg/ha) & 0.7 & 17.0 & 96 \\
TP (kg/ha) & 1.5 & 20.0 & 93 \\
SS (mg/ha) & 0.4 & 21.6 & 98 \\
E. coli (cfu) & $4.44 \mathrm{E}+10$ & $1.93 \mathrm{E}+11$ & 77 \\
\hline
\end{tabular}

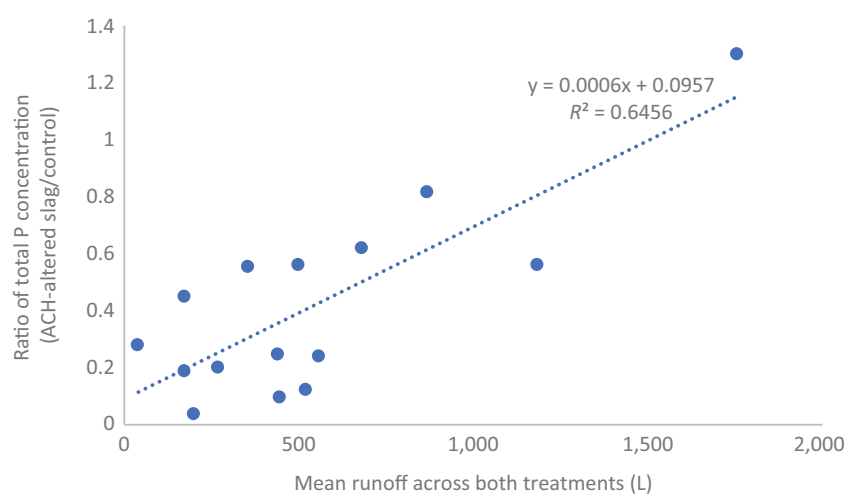

Figure 2. Relationship between mean runoff volume for the two treatments and the ratio of total $\mathrm{P}$ concentration in each event from the $\mathrm{ACH}$-altered slag compared to the control treatments. Ratios above 1 indicate no removal occurred.

Table 2: Mean \pm s.e. (range) of the volume of runoff and concentrations of $\mathrm{P}$ fractions, sediment and $E$. coli, and the probability of a significant difference between the $\mathrm{ACH}$-altered slag and control roadways

\begin{tabular}{lccc}
\hline Parameter & ACH-altered slag & Control & $\begin{array}{c}\text { Significant difference } \\
\text { (probability for } t \text {-test) }\end{array}$ \\
\hline Runoff (L) & $367 \pm 69(53-1,760)$ & $588 \pm 123(53-1,751)$ & 0.574 \\
DRP (mg/L) & $0.060 \pm 0.013(0.004-1.560)$ & $0.301 \pm 0.053(0.004-2.312)$ & 0.001 \\
DOP (mg/L) & $0.149 \pm 0.049(0.001-0.906)$ & $0.135 \pm 0.022(0.001-0.571)$ & 0.798 \\
PP (mg/L) & $0.604 \pm 0.048(0.240-6.860)$ & $2.046 \pm 0.556(0.010-6.640)$ & 0.010 \\
TP (mg/L) & $0.813 \pm 0.136(0.176-7.623)$ & $2.482 \pm 0.590(0.166-8.853)$ & 0.006 \\
SS (mg/L) & $395 \pm 93(240-13,680)$ & $2,720 \pm 1,103(26-4,950)$ & 0.049 \\
E. coli (cfu 100/mL) & $3,629 \pm 1,406(100-24,190)$ & $5,755 \pm 1,901(50-14,500)$ & $0.088^{2}$ \\
\hline
\end{tabular}

${ }^{1}$ Number of runoff events $=18$.

${ }^{2}$ Data required log transformation for comparison of means. 


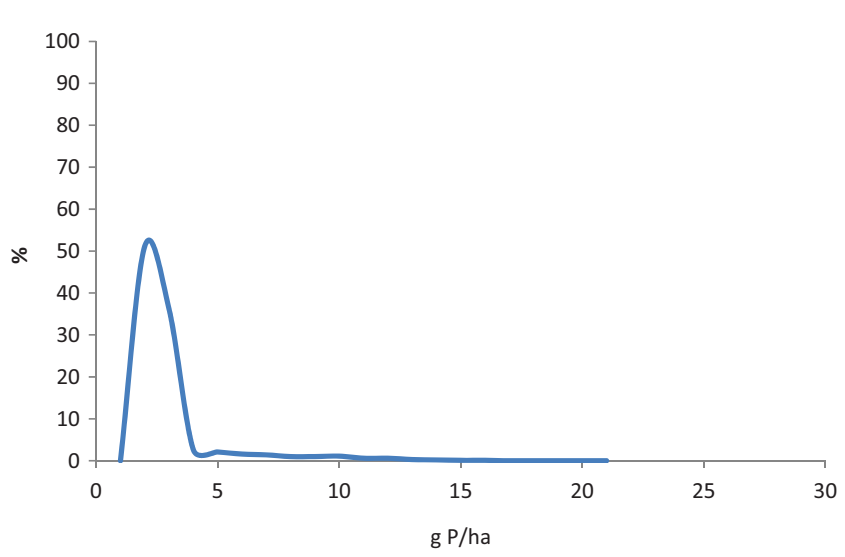

Figure 3. Probability distribution of $\mathrm{g} P$ day deposited on a hectare of roadway. This can be multiplied by cow number and time period; for example, $3 \mathrm{~g}$ TP $\times 100$ cows $\times 365$ days $=\sim 100 \mathrm{~kg}$.

shows that for approximately $50 \%$ of outcomes, $2.5 \mathrm{~g} \mathrm{TP} / \mathrm{ha}$ was available to be lost in runoff. When this is converted into a load using the runoff data presented in Table 3 the minimum TP load is $7.7 \mathrm{~kg} / \mathrm{ha}$ and the maximum is $462.2 \mathrm{~kg} / \mathrm{ha}$.

\section{Discussion}

It should be noted that this trial did not have spatial replication nor directly measure manure loads. As such our findings should be taken as a proof of concept, informing the design of a more comprehensive study.

Considering that deposition of dung on the roadway occurs daily, concentrations of $P$ lost are about one-fifth of those expected in runoff from a fresh dung patch as documented by McDowell (2006). However, this does depend on the rate of drying, diet and above all climatic conditions.

Installing $\mathrm{ACH}$-altered slag alongside a roadway could be viewed as like an active filter bed used as pre or post treatment for wetlands (Ballantine \& Tanner, 2010). These beds are influenced by flow rates and the concentration of inflowing water. In studying active filters with steel melter slag as a retention material, Shilton et al. (2005) noted that overall $P$ removal from inflowing waste (piggery effluent or domestic effluent) water in two steel melter slag filters - one at Ashurst and another at Waiuku (New Zealand) - was 72 and $77 \%$, respectively, but was most efficient in summer and autumn during low flows. Our data indicated a similar effect in that DRP load from the $\mathrm{ACH}$-altered slag treatment was much lower than that of the control section at lower flows, but decreased at higher flows becoming ineffective when $>1,000 \mathrm{~L}$ of runoff or $40 \mathrm{~mm}$ of rainfall occurred resulting in the filter being overtopped (Figure 2).
The cost per $\mathrm{kg}$ of $\mathrm{P}$ retained by unaltered steel melter slag when used in P-socks in a streambed to remove $P$ from baseflow was estimated to be 30 USD (McDowell et al., 2007), which precluded its use when compared to dosing streams with alum (at about $10 \mathrm{USD} / \mathrm{kg} \mathrm{P}$ precipitated) (Pilgrim \& Brezonik, 2005), but was more cost-effective than dosing the roadway directly with alum (McDowell \& Nash, 2012; Smith \& McDowell, 2016). However, the difference in cost between $\mathrm{ACH}$-altered slag and unaltered slag is negligible as it is a waste material and the $1 \%$ solution of $\mathrm{ACH}$ is cheap. The resulting cost effectiveness would be about 3 USD/kg $P$ retained. However, this would vary according to site characteristics (e.g. slope) and frequency of road use by cattle. It is also likely that the P-sorption capacity of the $\mathrm{ACH}$-altered slag would decrease with time as sorption sites became occupied. Although the $\mathrm{P}$ sorption capacity of a similar product was not exceeded when included as part of a backfill for an artificial drainage network, this was exposed to much less sediment load (McDowell et al., 2008). We have no data to confirm the longevity of our material beyond the 12-mo length of the trial. It should also be noted that other filter media may be more suited to a specific geographical location. Decision support tools are now available to help match pollutant and filter medium type (Ezzati et al., 2019). In terms of the uncertainty analysis results the present study falls within the lower range of potential losses, that is, $20 \mathrm{~kg} / \mathrm{ha}$. This range represents all possible sites where deposit weight, TP content and number of deposits range within a hectare of roadway. Preliminary data suggests that the use of $\mathrm{ACH}$ altered slag was effective at mitigating $P$ losses in runoff from a roadway ( $93 \%$ of TP) supplying $P$ loss into the Mangakino stream. We therefore recommend the use of a material like $\mathrm{ACH}$-altered slag to remove $\mathrm{P}$ from runoff from roadways entering streams. However, the uncertainty analysis did suggest that the deposition of dung-P on the roadway could be higher, which may reduce the efficiency of the $\mathrm{ACH}$-altered to retain P. A reduced efficiency would need to be factored into the design of any filter bed.

\section{Acknowledgements}

The study was funded by Environment Bay of Plenty. Steel slag was supplied by SteelServ, Waiuku, South Auckland. We thank the Our Land and Water National Science Challenge for funding the first author while writing-up the study (contract C10X1507 from the New Zealand Ministry of Business, Innovation and Employment). The Monte Carlo analysis work was funded by the Irish Environmental Protection Agency and Department of Agriculture, Food and the Marine as part of the ROADRUNNER project; grant number 2018-W-MS-38. 


\section{References}

Abell, J., Özkundakci, D. and Hamilton, D. 2010. Nitrogen and phosphorus limitation of phytoplankton growth in New Zealand lakes: implications for eutrophication control. Ecosystems 13: 966-977.

Abell, J.M., Özkundakci, D., Hamilton, D.P. and Miller, S.D. 2011. Relationships between land use and nitrogen and phosphorus in New Zealand lakes. Marine and Freshwater Research 62: 162-175.

Andersen, H.E., Windolf, J. and Kronvang, B. 2016. Leaching of dissolved phosphorus from tile-drained agricultural areas. Water Science and Technology 73: 2953-2958.

Australian and New Zealand Governments. 2018. Australian and New Zealand Guidelines for Fresh and Marine Water Quality. Australian and New Zealand Governments and Australian state and territory governments, Canberra, ACT, Australia.

Bacher, M.G., Fenton, O., Bondi, G., Creamer, R.E., Karmarkar, M. and Schmidt, O. 2018. The impact of cattle dung pats on earthworm distribution in grazed pastures. BMC Ecology 18: 59. doi:10.1186/s12898-018-0216-6.

Ballantine, D.J. and Tanner, C.C. 2010. Substrate and filter materials to enhance phosphorus removal in constructed wetlands treating diffuse farm runoff: a review. New Zealand Journal of Agricultural Research 53: 71-95.

Bell, M., Rees, R., Cloy, J., Topp, K., Bagnall, A. and Chadwick, D. 2015. Nitrous oxide emissions from cattle excreta applied to a Scottish grassland: effects of soil and climatic conditions and a nitrification inhibitor. Science of the Total Environment 508: 343-353.

Buda, A.R., Koopmans, G.F., Bryant, R.B. and Chardon, W.J. 2012. Emerging technologies for removing nonpoint phosphorus from surface water and groundwater: introduction. Journal of Environmental Quality 41: 621-627.

Davies-Colley, R.J., Nagels, J.W., Smith, R.A., Young, R.G. and Phillips, C.J. 2004. Water quality impact of a dairy cow herd crossing a stream. New Zealand Journal of Marine and Freshwater Research 38: 569-576.

Eisenreich, S.J., Bannerman, R.T. and Armstrong, D.E. 1975. A simplified phosphorus analysis technique. Environmental Letters 9: 43-53.

Ezzati, G., Healy, M.G., Christianson, L., Feyereisen, G.W., Thornton, S., Daly, K. and Fenton, O. 2019. Developing and validating a decision support tool for media selection to mitigate drainage waters. Ecological Engineering: X 2: 100010.

Haynes, R.J. and Williams, P.H. 1993. Nutrient cycling and soil fertility in the grazed pasture ecosystem. Advances in Agronomy 49: 119-199.

Hively, W.D., Gérard-Marchant, P. and Steenhuis, T.S. 2006. Distributed hydrological modeling of total dissolved phosphorus transport in an agricultural landscape, part II: dissolved phosphorus transport. Hydrology and Earth System Sciences Discussions 10: 263-276.
Karczmarczyk, A., Bus, A. and Baryła, A. 2016. Filtration curtains for phosphorus harvesting from small water bodies. Ecological Engineering 86: 69-74.

Krol, D.J, Carolan, R., Minet, E., McGeough, K.L., Watson, C.J., Forrestal, P.J., Lanigan, G.J. and Richards, K.R. 2016. Improving and disaggregating $\mathrm{N} 2 \mathrm{O}$ emission factors for ruminant excreta on temperate pasture soils. Science of the Total Environment 568: 327-338.

McDowell, R.W. 2006. Contaminant losses in overland flow from cattle, deer and sheep dung. Water, Air, and Soil Pollution 174: 211-222.

McDowell, R.W. and Nash, D. 2012. A review of the cost-effectiveness and suitability of mitigation strategies to prevent phosphorus loss from dairy farms in New Zealand and Australia. Journal of Environmental Quality 41: 680-693.

McDowell, R.W., Hawke, M. and McIntosh, J.J. 2007. Assessment of a technique to remove phosphorus from streamflow. New Zealand Journal of Agricultural Research 50: 503-510.

McDowell, R.W., Sharpley, A.N. and Bourke, W. 2008. Treatment of drainage water with industrial by-products to prevent phosphorus loss from tile-drained land. Journal of Environmental Quality 37: 1575-1582.

Monaghan, R.M. and Smith, L.C. 2012. Contaminant losses in overland flow from dairy farm laneways in southern New Zealand. Agriculture, Ecosystems \& Environment 159: 1 70-175.

Oudshoorn, F.W., Kristensen, T. and Nadimi, E.S. 2008. Dairy cow defecation and urination frequency and spatial distribution in relation to time-limited grazing. Livestock Science 113: 62-73.

Pilgrim, K.M. and Brezonik, P.L. 2005. Evaluation of the potential adverse effects of lake inflow treatment with alum. Lake and Reservoir Management 21: 77-87.

Shilton, A., Pratt, S., Drizo, A., Mahmood, B., Banker, S., Billings, L., Glenny, S. and Luo, D. 2005. 'Active' filters for upgrading phosphorus removal from pond systems. Water Science and Technology 51: 111-116.

Smith, L.C. and McDowell, R.W. 2016. The use of alum to decrease phosphorus loss from dairy farm laneways in southern New Zealand. Soil Use and Management 32: 69-71.

Vadas, P.A., Busch, D.L., Powell, J.M. and Brink, G.E. 2015. Monitoring runoff from cattle-grazed pastures for a phosphorus loss quantification tool. Agriculture, Ecosystems \& Environment 199: 124-131.

Watanabe, F.S. and Olsen, S.R. 1965. Test of an ascorbic acid method for determining phosphorus in water and $\mathrm{NaHCO} 3$ extracts from soil. Soil Science Society of America Journal 29: 677-678.

Withers, P.J.A., Jarvie, H.P. and Stoate, C. 2011. Quantifying the impact of septic tank systems on eutrophication risk in rural headwaters. Environment International 37: 644-653. 